\title{
Is the Tokyo Foreign Exchange Market Efficient from Two Perspectives of Forward Bias and Anomaly?
}

\author{
Yutaka Kurihara \\ Department of Economics, Aichi University, Aichi, Japan \\ E-mail: kurihara@vega.aichi-u.ac.jp \\ Received April 23, 2011; revised June 13, 2011; accepted June 23, 2011
}

\begin{abstract}
This paper examines the efficiency of the Tokyo Foreign Exchange Market from two perspectives. One is whether or not forward bias in this market has existed and the other is the effect of interventions in the market with a focus on whether or not a day-of-the-week anomaly exists in it. Empirical results show that forward exchange rates are a biased predictor of future spot exchange rates; however, there are some anomalies in the market. The findings suggest the conclusion that this market has not been completely efficient.
\end{abstract}

Keywords: Anomaly, Exchange Rate, Foreign Exchange Market, Intervention

\section{Introduction}

Many papers have investigated foreign exchange markets and exchange rates not only from the view of theoretical aspects but also from empirical ones. Above all, market efficiency has received much attention and many analyses have been conducted. This paper focuses on 1) whether or not forward bias has existed and 2) anomalous (day-of-the-week) effects produced by interventions in the market. ${ }^{1}$

For interest rate parity, many researchers have tackled the problem of the forward bias or forward premium puzzle along with the condition of covered or uncovered interest rate parity. Their results have not been inclusive; however, most studies have concluded that covered interest rate parity (CIP) holds in most recent cases but that uncovered interest rate parity (UIP) does not. Evidence and findings have been mixed. For example, Fatum and Hutchison (2003) [2] and Fatum and Pederson (2009) [3] supported this view but Aguilar and Nydalh (2000) [4] did not. Recent studies have examined the reason that the condition does not hold.

Louis et al. (1999) [5] showed that forward markets that have been tested have become efficient in the sense that CIP holds well. Cook (2009) [6] found little or even a negative relationship between expected excess returns on exchange rates for adjusted U.S. money market rates. Batten and Szilagyi (2010) [7] indicated that evidence of

${ }^{1}$ Yamori and Kurihara (2006) [1] examined day-of- the week anomalies in foreign exchange markets in $1980 \mathrm{~s}$ and $1990 \mathrm{~s}$. declining deviations from equilibrium is consistent with a more efficient trading environment. Fong et al. (2010) [8] showed that CIP arbitrage deviations include compensation for liquidity and credit risk.

The hypothesis for the formation of exchange rate expectations may be one reason that interest rate parity, especially UIP, does not hold. Exchange rate expectations are usually assumed to be adaptive or rational. However, in the real world, exchange rate forecasters are heterogeneous. Much attention has been paid to this heterogeneity. Heterogeneity in exchange rates seems to be a major source of volatility. Smith and Pitts (2006) [9] empirical results suggested strong conditional heteroskedasticity, as well as contemporaneous correlation, in the mean-corrected volume measure. Kim and Sheen (2006) [10] and Chari (2007) [11] suggested an asymmetric volatility in central bank threshold effects. Bertoli et al. (2011) [12] showed that the relationship between exchange misalignment and forecast heterogeneity is important for the so-called coordination channel of intervention. It should be noted that recent papers about central bank intervention seem to shed light on heterogeneity for policy tools. ${ }^{2}$

Almost all of the aforementioned articles have shown that forward premium is inversely related to future ex-

\footnotetext{
${ }^{2}$ Shah et al. (2009) [13] showed the same results in the case of Pakistan Breedon and Vitale (2010) [14] suggested that the strong contemporaneous correlation between order flow and exchange rates is largely due to portfolio-balance effects. Marsh (2010) [15] also indicated that strong contemporaneous correlation between order flows and exchange rate changes essentially disappears on days when the Bank of Japan intervenes.
} 
change rate changes or excess returns, as shown by Fama (1984) [16]. Recently, Lyons (2001) [17] showed a reason for the occurrence of the forward premium puzzle. ${ }^{3}$ Lyons noted that the forward bias in foreign exchange markets does not attract speculative funds until the trading strategy is expected to bring an excess return that exceeds that of other trading strategies. This indicates a band of inaction in which the forward bias will continue until it is large enough to attract speculative funds. Sarno et al. (2006) [23] supported this idea by employing nonlinear models that incorporated the band of inaction.

Few recent studies have analyzed this forward bias, especially in the Tokyo market. Forward bias is accepted rejection of the UIP, which indicates that forward exchange rates are a biased predictor of future spot exchange rates. After an examination of this perspective, this article addresses anomaly, namely day-of-the-week, and the effects of interventions.

This paper also focuses on foreign exchange market interventions and examines their effectiveness in the market. Marsh (2010) [15] indicated that strong contemporaneous correlation between order flows and exchange rate changes essentially disappear on days when the Ministry of Finance (Bank of Japan) intervenes. Kim and Le (2010) [22] suggested that interventions conducted during periods of oral intervention were in general more effective in moving the exchange rate in the desired direction. Bertoli et al. (2010) [12] showed that the relationship between exchange misalignment and forecast heterogeneity is important for the so-called coordination channel of intervention. Many papers about intervention have been published; however, unique among these, this paper examines day-of-the-week effects in the Tokyo Foreign Exchange Market. Along with large fluctuations of exchange rates, some countries intervene in the foreign exchange markets to attain stable exchange rates or to avoid too much currency appreciation. An examination of the effectiveness and influence on the markets of this approach is very important.

The article is structured as follows: Section 2 provides the two models for the foreign exchange market efficiency. Section 3 explains the data employed here. Section 4 reveals the empirical method and provides empirical analyses. Finally, Section 5 makes a brief conclusion.

\footnotetext{
${ }^{3}$ Some studies have focused on sterilized interventions in foreign exchange markets. See Klein and Rosengren (1991) [18], Dominguez $(1992,1993)[19,20]$. Reiz and Taylor (2008) [21] proposed that coordination channeled through intervention may be effective. Bertoli et al. (2010) [12] employed the exchange market pressure (EMP) index and suggested that the index is sensitive to some assumptions behind the information available, especially when markets are involved. Kim and Le (2010) [22] also suggested that the interventions conducted during the periods of oral intervention were in general more effective in the moving exchange rate in the desired direction.
}

\section{Empirical Analyses}

\subsection{A Model for Forward Bias}

Forward bias is a broadly accepted empirical rejection of the UIP condition that suggests that forward exchange rates are a biased predictor of future spot exchange rates. Also, forward bias indicates that returns to currency speculation are predictable, so they generate high economic value to risk-averse investors who design dynamic allocation strategies to avoid the UIP violation. This is evident in the recent surge in capital flows all over the world due to the spread of the use of some kinds of strategies that exploit the forward bias anomaly in the real world. Financial institutions around the world tackle this transaction every day.

To check whether or not this UIP condition is accurate and determine whether forward bias exists, the following method is most commonly employed for empirical analysis:

$$
s_{t+n}-s_{t}=\alpha+\beta\left(f_{t}-s_{t}\right)+\varepsilon_{t+n}
$$

where $s_{t+n}$ is the logarithm of spot exchange rate at time $t+n, f_{t}$ is the logarithm of the forward rate for the horizon $\mathrm{n}, \alpha=0$ and $\beta=1$, and $\varepsilon_{t+n}$ is an error term that can follow up to an $n-1$ moving average error term under the null of efficiency.

The Fama regression (1984) [16] is used to determine whether the current forward premium $f_{t}-s_{t}$ is an unbiased predictor of the future spot exchange rate return $\left(s_{t+n}-s_{t}\right)$. When agents are risk-neutral and have rational expectations, $\alpha=0$ and $\beta=1$, and both of them are significant. The error term should be serially uncorrelated.

\subsection{A Model for Intervention Efficiency}

This paper employs the empirical GARCH (generalized autoregressive conditional heteroskedasticity) model to examine the effectiveness of interventions on exchange rates. GARCH is designed to model and forecast conditional variances. The variance of the dependent variable is modeled as a function of past values of the dependent variable and independent or exogenous variables.

To control for the other activity of central banks that may affect exchange rates, interest rate (INTEREST) and the expectation of exchange rate (EXPECT) are included in the equation as follows:

$$
\text { Exchanget }=\alpha 0+\sum_{i=1}^{5} \alpha 1 \text { Dit }+\alpha 6 \text { Interventiont }+\beta E(Z)
$$

where Exchange is percent log difference of Japanese yen/U.S. dollar exchange rate, D1t, D2t, D3t, D4t, D5t, 
are day-of-the-week dummy variables for Monday, Tuesday, Wednesday, Thursday, and Friday, respectively with Saturday as a reference point. Intervention is the Bank of Japan's intervention in the foreign exchange market (a positive value means net purchase of foreign currency in U.S. dollars). $E(Z)$ is the vector of other relevant explanatory variables (interest rate and the expectation of exchange rate).

\section{Data}

The data (exchange rates and interest rate) are from Nikkei Needs (Japanese Nippon KeizaiShinbun, Inc.) and the Japanese Ministry of Finance in Japan (the day of intervention and the volume). Forward exchange rates are for one month. All of the exchange rates are daily averages. Prediction data are obtained from AR(1). Interest rates are money market overnight rates. The sample period is 1993 to 2010 . Time series properties of the data are examined. Except for the log of the exchange rate, all of the data are stationary according to an augmented Dickey-Fuller (ADF) test. The log of the exchange rate is integrated at order one and thus becomes stationary.

\section{Empirical Analysis}

\subsection{Forward Bias}

Table 1 reports the standard regression results for forward bias.

The forward premium $\left(f_{t}-s_{t}\right)$ has a positive coefficient of 1.1263 and is significantly different from zero at the $1 \%$ level. The coefficient is almost one. In most similar studies, the value of $\beta$ takes minus, which is called forward premium puzzle; however, this result is different from such cases. The constant term is almost zero and significant. Forward exchange rates seem to be a predictor of future spot exchange rates. Recently in Japan, exchange rate movements frequently seem not to be in accordance with interest rates (domestic and foreign) movements. For example, Japanese low or zero interest rates result in appreciation of the yen; however, forward exchange rates can be a predictor of future spot exchange rates.

This interpretation of the results is difficult; however, when deviations from the condition of CIP are large, the forward premium will become a more accurate forecast of future changes in the expected spot rate. Consequently, as deviations from CIP become large and the coefficients of the forward premium become smaller, the bias of the forward premium as a predictor of future changes in spot exchange rates becomes smaller. For the constant term, there would be some possibility of the existence of transactions costs as the term is significant. However, again, the value is almost zero (0.0311). If transaction costs effects exist, they would be small.

\subsection{Intervention Efficiency and Effectiveness}

Before estimating the GARCH model for the analysis of market intervention, it is necessary to understand the impact of the intervention on exchange rate volatility. The results of Granger's causality test show that there is unidirectional causality between the intervention and unconditional exchange rate volatility. Volatility was measured using the squared log difference of exchange rate. Table 2 shows the result of interventions in the Japanese Foreign Exchange Market using the GARCH model.

Model A shows that two days (Monday and Friday) of the day-of-the-week variables are significant in the equation. There is evidence of statistically significant day-ofthe-week effects. The market is closed on Saturday and Sunday, so anomalies may exist. Also, the purchase of the U.S. dollar brings unexpected appreciation of the Japanese yen. However, it is not significant.

On the other hand, the Model B equation includes relevant exogenous explanatory variables and uses one-day time lag intervention. The results are almost as expected. One-day time lag interventions have a significant effect on the exchange rate as expected. The purchase (sale) of the U.S. dollar brings depreciation (appreciation) of the Japanese yen. The sign of INTEREST is negative as expected but is not significant. The expectation of the exchange rate has a correct significant impact on the exchange rate changes.

Table 1. Regression Results for Forward Bias.

\begin{tabular}{ccc}
\hline Constant & $0.0537(1.6050)$ & $1.6050^{*}$ \\
\hline ft-st & $1.1263(12.2369)$ & $12.2369 * * *$ \\
Adj.R ${ }^{2}$ & \multicolumn{3}{c}{0.0311} & \\
\hline
\end{tabular}

Note. *** denotes significant at $1 \%$, ** at $5 \%$, and * at $10 \%$ respectively.

Table 2. Results of Interventions in the Japanese Foreign Exchange Market.

\begin{tabular}{ccccc}
\hline & \multicolumn{2}{c}{ Model A } & \multicolumn{2}{c}{ Model B } \\
\cline { 2 - 5 } & Coefficient & t value & Coefficient & t value \\
\hline Constant & 0.0070 & 0.5620 & -0.2426 & $-2.0160^{* *}$ \\
Monday & -0.3771 & $-3.5678^{* * *}$ & -0.3951 & $-3.7410^{* * *}$ \\
Tuesday & -0.3128 & -0.9769 & -0.4083 & -0.8156 \\
Wednesday & -0.2030 & -0.8888 & -0.2832 & -0.6444 \\
Thursday & -0.060 & -0.6770 & -0.0940 & -1.0560 \\
Friday & -0.1782 & $-1.7197^{* *}$ & -0.2140 & $-2.0653^{* *}$ \\
Intervention & -0.00001 & -0.8116 & -0.00003 & $-2.0451^{* *}$ \\
Intervention & & & 0.00009 & $7.6105^{* * *}$ \\
(-1) & & & -0.0008 & -1.1065 \\
INTEREST & & & 0.0022 & $2.0651^{* *}$ \\
EXPECT & \multicolumn{2}{c}{0.1403} \\
Adj.R2 & 0.0848 & \multicolumn{2}{c}{} \\
\hline
\end{tabular}

Note. $* * *$ denotes significant at $1 \%$, ** at $5 \%$, and * at $10 \%$ respectively. 


\section{Conclusions}

This paper performed an empirical analysis of the Tokyo Foreign Exchange Market from two perspectives: forward bias and anomaly. Contrary to most studies that have analyzed different markets and time periods, forward exchange rates are a predictor of future spot exchange rate. Judging only from this result, this market is efficient.

This paper also employed the GARCH model to examine the efficiency and effectiveness of the daily foreign exchange market in Japan and found day-of-theweek anomalies in the market. Also, foreign exchange market interventions influence the exchange rate level as expected. The intervention is effective in changing the exchange level, but the contemporaneous effect had a reverse sign. For the anomalies, day-of-the-week effect was examined and there are some kinds of anomalies (Monday and Friday). The results showed that this market was not efficient. Closing days in the market may cause anomalies.

The selected exchange rate, the sample period examined, and the empirical method or theoretical model employed could change the results. Also, coordination channeled through foreign exchange market interventions may be effective in that they attract the fundamentals. Moreover, some studies have shown that central bank interventions tend to increase exchange rate volatility. ${ }^{4}$ There may be some room for further research.

\section{Acknowledgements}

I thank anonymous referees and Akihiro Amano for their valuable comments and suggestions.

\section{Reference}

[1] N. Yamori and Y. Kurihara, "The Day-of-the-Week Effect in Foreign Exchange Markets: Multi-currency Evidence," Research in International Business and Finance, Vol. 18, No. 1, 2004, pp. 51-57. doi:10.1016/j.ribaf.2004.02.004

[2] R. Fatum and M. M. Hutchison, "Effectiveness of Official Daily Foreign Exchange Market Intervention Operations in Japan,” NBER Working Paper, No. 9648, 2003.

[3] R. Fatum and J. Pedersen, "Real-Time Effects of Central Bank Intervention in the Euro Market," Journal of International Economics, Vol. 78, No. 1, 2009, pp. 11-25. doi:10.1016/j.jinteco.2009.02.011

[4] J. Aguilar and S. Nydalh, "Central Bank Intervention and Exchange Rate: the Case of Sweden,” Journal of Interna-

${ }^{4}$ See Benie et al. (2000, 2007, 2009) [24-26], for example. However, other studies, for example, Eijffinger and Gruijters (1991) [27], Dominguey (1992) [19], and Pasquariello (2010) [28] showed that foreign exchange interventions reduce exchange rate volatility. tional Financial Markets, Institutions and Money, Vol. 10, 2000, pp. 303-322.

doi:10.1016/S1042-4431(00)00041-X

[5] H. Louis, L. P. Blenman and J. S. Thatcher, "Interest Rate Parity and the Behavior of the Bid-Ask Spread," The Journal of Financial Research, Vol. 22, No. 2, 1999, pp. 189-200.

[6] D. Cook, "The Puzzling Dual of the Uncovered Interest Parity Puzzle Evidence from Pacific Rim Capital Flows,” International Review of Economics and Finance, Vol. 18, No. 3, 2009, pp. 449-460. doi:10.1016/j.iref.2008.09.009

[7] J. A. Batten and P. G. Szilagyi, "Is Covered Interest Parity Arbitrage Extinct? Evidence from the Spot USD/ Yen,” Applied Economics Letters, Vol. 17, No. 3, 2010, pp. 283-287. doi:10.1080/13504850701720189

[8] W. M. Fong, G. Valente and J. K. W. Fung, "Covered Interest Arbitrage Profits: The Role of Liquidity and Credit Risk," Journal of Banking and Finance Amsterdam, Vol. 34, No. 5, 2010, pp. 1098-1110.

[9] M. Smith and A. Pitts, "Foreign Exchange Intervention by the Bank of Japan: Bayesian Analysis Using a Bivariate Stochastic Volatility Model,” Econometric Reviews, Vol. 25, No. 2-3, 2006, pp. 425-440. doi:10.1080/07474930600712897

[10] S. Kim and J. Sheen, "Interventions in the Yen-Dollar Spot Market: A Story of Price, Volatility and Volume," Journal of Banking and Finance, Vol. 30, No. 11, 2006, pp. 3191-3210. doi:10.1016/j.jbankfin.2005.12.005

[11] A. Chari, "Heterogeneous Market-Making in Foreign Exchange Markets: Evidence from Individual Bank Responses to Central Bank Interventions," Journal of Money, Credit, and Banking, Vol. 39, No. 5, 2007, pp. 1131-1145. doi:10.1111/j.1538-4616.2007.00060.x

[12] S. Bertoli, M. Giampiero and G. G. Ricchiuti, "Exchange Market Pressure: Some Caveats in Empirical Applications,” Applied Economics, Vol. 42, 2011, pp. 24-35.

[13] M. K. A. Shah, Z. Hyder and M. K. Pervaiz, "Central Bank Intervention and Exchange Rate Volatility in Pakistan: An Analysis Using GARCH-V Model,” Applied Financial Economics, Vol. 19, 2009, pp. 1497-1508. doi:10.1080/09603100902967553

[14] F. Breedon and P. Vitale, “An Empirical Study of Portfolio-Balance and Information Effects of ORDER flow on Exchange Rates," Journal of International Money and Finance, Vol. 29, No. 3, 2010, pp. 504-520. doi:10.1016/j.jimonfin.2009.07.001

[15] I. Marsh, “Order Flow and Central Bank Intervention: An Empirical Analysis of Recent Bank of Japan Actions in the Foreign Exchange Market,” Journal of International Money and Finance, Vol. 30, 2010, pp. 377-390. doi:10.1016/j.jimonfin.2010.10.001

[16] E. Fama, "Forward and Spot Exchange Rates," Journal of Monetary Economics, Vol. 14, 1984, pp. 319-338. doi:10.1016/0304-3932(84)90046-1 
[17] R. K. Lyons, “The Microstructure Approach to Exchange Rates,” MIT Press, Cambridge, 2001.

[18] M. Klein and E. Rosengren, "Foreign Exchange Intervention as a Signal of Monetary Policy," New England Economic Review, May-June 1991, pp. 39-50.

[19] K. M. Dominguez, "Does Central Bank Intervention Increase Volatility of Foreign Exchange Rates?” Harvard University, Cambridge, 1992.

[20] K. M. Dominguez, "Does Foreign Exchange Intervention Matter? The Portfolio Effect," American Economic Review, Vol. 83, 1993, pp. 1356-1369.

[21] S. Reiz and M. P. Taylor, "The Co-ordination Channel of Foreign Exchange Intervention: A Nonlinear Microstructural Analysis,” European Economic Review, Vol. 52, 2008, pp. 55-76. doi:10.1016/j.euroecorev.2007.06.023

[22] S. Kim and A. T. Le, “Secretary of Bank of Japan's yen intervention: Evidence of Efficiency from Intra-Daily Data," Journal of the Japanese and International Economies, Vol. 24, No. 3, 2010, pp. 369-380. doi:10.1016/j.jjie.2010.02.002

[23] L. Sarno, G. Valente and H. Leon, "Nonlinearity in Deviations from Uncovered Interest Parity: An Explanation of the Forward Bias Puzzle," Review of Finance, Vol. 10, 2006, pp. 443-482. doi:10.1007/s10679-006-9001-z

[24] M. Benie, J. Lahaye, S. Laurent, C. J Neely and F. C. Palm, "Central Bank Intervention and Exchange Rate Volatility, Its Continuous and Jump Components,” International Journal of Finance and Economics, Vol. 12, 2000, pp. 201-223.

[25] M. Benie, A. Benassy-Quere and R. MacDonald, "The Impact of Central Bank Intervention on Exchange-Rate Forecast Heterogeneity,” Journal of Japanese International Economics, Vol. 21, 2007, pp. 38-63.

[26] M. Benie, M. Jassen and C. Lecourt, "Should Central Bankers Talk to the Foreign Exchange Markets,” Journal of International Money and Finance, Vol. 28, 2009, pp. 776-790. doi:10.1016/j.jimonfin.2008.08.003

[27] S. C. Eijffinger and N. P. D. Gruijters, "On the Short Term Objectives of Daily Intervention by the DeucheBundes Bank and the Federal Reserve System in the US Dollar/Deutsche Mark Exchange Market," Kreditandkapital, Vol. 24, 1991, pp. 50-72.

[28] P. Pasquariello, “Central Bank Intervention and the Intraday Process of Price Formation in the Currency Markets," Journal of International Money and Finance, Vol. 29, 2010, pp. 1045-1061. doi:10.1016/j.jimonfin.2010.02.002 